\title{
Autoimmune encephalitis in a South Asian population
}

Nilanka Wickramasinghe ${ }^{1}$, Dhanushka Dasanayake ${ }^{2}$, Neelika Malavige ${ }^{3}$, Rajiva de Silva $^{2}$ and Thashi Chang ${ }^{4^{*}}$

\begin{abstract}
Background: Autoimmune encephalitis (AE) is now considered a main, potentially curable cause of encephalitis, but remains conspicuously underreported from South Asia. We studied the clinical characteristics in relation to their antibody status and outcomes of patients presenting with AE in Sri Lanka.

Methods: Patients admitting to government hospitals who were clinically suspected of AE by an on-site neurologist were prospectively recruited over a period of 12 months. Sera and cerebrospinal fluid were tested for NMDAR, AMPAR1, AMPAR2, LGI1, CASPR2, GABARB1/B2 antibodies (Ab) using commercial cell-based assays. Demographic, clinical and laboratory data were compiled into an investigator-administered proforma. Patients were reviewed at 1 year follow up either in person or via telephone.

Results: One-hundred and forty-two patients from 21 of 25 districts in Sri Lanka (median age $=20.5$ years; range 1-86 years; females $=61.3 \%)$ were recruited. Of them, 65 (45.8\%; median age $=19$ years; range $1-86$ years; females $=64.6 \%)$ fulfilled diagnostic criteria for probable NMDAR-antibody encephalitis (NMDARE) and 6 (4.2\%; median age $=44$ years; range 28-71 years; females $=83.3 \%$ ) limbic encephalitis (LE). Abnormal behaviour (95.3\%), seizures (81.5\%) and movement disorders (69.2\%) were the most frequent clinical manifestations of probable NMDARE. NMDAR-antibodies were detectable in $29(44.6 \%)$ and not detectable in 36 in CSF of probable-NMDARE patients. Abnormal EEG was more frequent $(p=0.003$ ) while a worse outcome ( $\mathrm{OR}=2.78 ; 95 \% \mathrm{Cl}=0.88-9.09)$ and deaths $(\mathrm{OR}=2.38 ; 95 \% \mathrm{Cl}=0.67-8.33)$ were more likely in antibody-negative than antibody-positive probable-NMDARE. Most patients with LE had amnesia (50\%) and/or confusion (100\%) with agitation (83.3\%) and seizures (100\%) but none had detectable antibodies to any of the antigens tested.
\end{abstract}

Conclusions: NMDARE is the commonest type of AE among South Asians as is the case worldwide. Clinical presentations of NMDARAb-positive and NMDARAb-negative AE patients do not significantly differ but EEG may be a useful marker of an autoimmune basis for psychiatric symptoms.

Keywords: Autoimmune, Encephalitis, Sri Lanka, NMDAR, Limbic, Antibody

\footnotetext{
* Correspondence: thashichang@gmail.com

${ }^{4}$ Department of Clinical Medicine, Faculty of Medicine, University of

Colombo, 25, Kynsey Road, Colombo 00800, Sri Lanka

Full list of author information is available at the end of the article
}

(c) The Author(s). 2021 Open Access This article is licensed under a Creative Commons Attribution 4.0 International License, which permits use, sharing, adaptation, distribution and reproduction in any medium or format, as long as you give appropriate credit to the original author(s) and the source, provide a link to the Creative Commons licence, and indicate if changes were made. The images or other third party material in this article are included in the article's Creative Commons licence, unless indicated otherwise in a credit line to the material. If material is not included in the article's Creative Commons licence and your intended use is not permitted by statutory regulation or exceeds the permitted use, you will need to obtain permission directly from the copyright holder. To view a copy of this licence, visit http://creativecommons.org/licenses/by/4.0/ The Creative Commons Public Domain Dedication waiver (http://creativecommons.org/publicdomain/zero/1.0/) applies to the data made available in this article, unless otherwise stated in a credit line to the data. 


\section{Background}

Among an estimated annual incidence of approximately 5 to 8 cases of encephalitis per 100,000 persons, autoimmune encephalitis (AE) has emerged as the third most common cause after infections, mostly viral, and acute disseminated encephalomyelitis [1]. More importantly, $\mathrm{AE}$ associated with autoantibodies directed against neuronal cell surface/synaptic proteins have emerged as the most treatment responsive encephalitis with the greatest potential for complete recovery [2]. Among the antibody mediated encephalitides, NMDAR-antibody encephalitis (NMDARE) is the most common followed by limbic encephalitis (LE) mediated by antibodies directed against LGI1, CASPR2, AMPAR or $\mathrm{GABA}_{B} \mathrm{R}$ while encephalitis mediated by other antibodies are rare [2]. NMDARE is characterised by a female predominance (4:1), younger onset (median age 21 years), associated tumours (ovarian teratoma) and a multi-phenomenological syndrome that evolves over time with seizures, abnormal movements, insomnia and irritability more frequent in children, and psychosis, abnormal behaviour, dysautonomia and coma more common in adults $[3,4]$. By contrast, LE is characterised by an older age of onset ( $>45$ years), amnesia, confusion, seizures, hyponatraemia, increased signal of medial temporal lobes on magnetic resonance imaging and variable association with tumours determined by the associated antibody [2, 3]. LGI1 antibodies account for most of the LE and is characterised by faciobrachial dystonic seizures that may predate cognitive impairment [5].

The population of South Asia accounts for about 40\% of Asia's population and about one quarter of the world's population. However, research on AE from this region remains sparse and limited mostly to case reports or series amounting to less than 200 cases among a 2 billion population [6-9]. Sri Lanka is an island of 65,610 $\mathrm{km}^{2}$, situated just south of the Indian subcontinent between northern latitudes $5^{\circ}$ to $10^{\circ}$ with a population of approximately 22 million. This study aimed to determine the prevalence of neuronal cell surface/synaptic protein binding autoantibodies, characterise the clinical manifestations and audit the treatment and outcomes among patients presenting to hospital with a syndrome clinically suggestive of AE in Sri Lanka.

\section{Methods}

All methods were performed in accordance with the relevant guidelines and regulations of the Ethics Review Committee of the Medical Research Institute, Colombo, Sri Lanka.

\section{Patients and samples}

Consecutive patients over the age of one-year meeting diagnostic criteria for 'possible' AE [10] as determined by an on-site consultant neurologist were prospectively recruited from patients admitted to government hospitals over a period of 12 months, and specimens of their sera and cerebrospinal fluid (CSF) were transported to the Department of Immunology, Medical Research Institute, Colombo, for testing. Patients who were HIVpositive or who had an alternative diagnosis that could mimic encephalitis such as psychiatric illness, metabolic disorders, epilepsy, post-anoxia, vasculitis, stroke and septicaemia, and in whom lumbar puncture was contraindicated were excluded. Written informed consent was obtained from the patient, next-of-kin or guardian. Serum and CSF were obtained from all patients when these specimens were collected as part of their diagnostic work up. Demographic, clinical and laboratory data including CSF analysis, blood investigations, brain imaging and electroencephalogram (EEG) results were compiled into a proforma that was provided to the Neurology Units in government hospitals by junior medical officers of the referring Unit. Data were verified by the research team via telephone conversation with referring physicians. Patients admitted to the two apex tertiary care hospitals in Colombo (National Hospital of Sri Lanka and Lady Ridgeway Hospital for children) and their hospital records were personally examined by the research team. Patients were reviewed after discharge from hospital at 1 year follow up either in person or via telephone.

Clinical classification of patients based on established diagnostic criteria for 'probable' NMDARE and LE [10] were done by researchers unaware of the antibody results.

\section{Laboratory analyses}

Undiluted CSF from all patients and 1:10 diluted serum from patients clinically suspected of LE, which can be negative in CSF, were assayed for autoantibodies binding to NMDAR, AMPA1 and AMPA2 receptors, LGI1, CASPR2 and GABAR B1/B2 $_{2}$ using Autoimmune Encephalitis Mosaic 6 kit from EUROIMMUN, Lübeck, Germany according to the manufacturer's instructions. The biochip slides were examined under indirect immunofluorescence microscope at $\times 20$ and $\times 40$ magnification by two independent assessors (TC and RdS) trained in cell-based assays and who were unaware of the clinical details of the patients. Specimens were classified as positive or negative based on the intensity of surface immunofluorescence in comparison with positive and negative controls provided in the kit (Fig. 1). The intensity was scored as 0 (=negative control), 1 (borderline positive) and 2 (=positive control). Both 1 and 2 were considered as positive.

Routine microbiological screening of CSF was performed using Gram stain, Ziehl Neelsen stain and culture on enriched culture media and when indicated, polymerase chain reaction assay for Herpes simplex virus. 

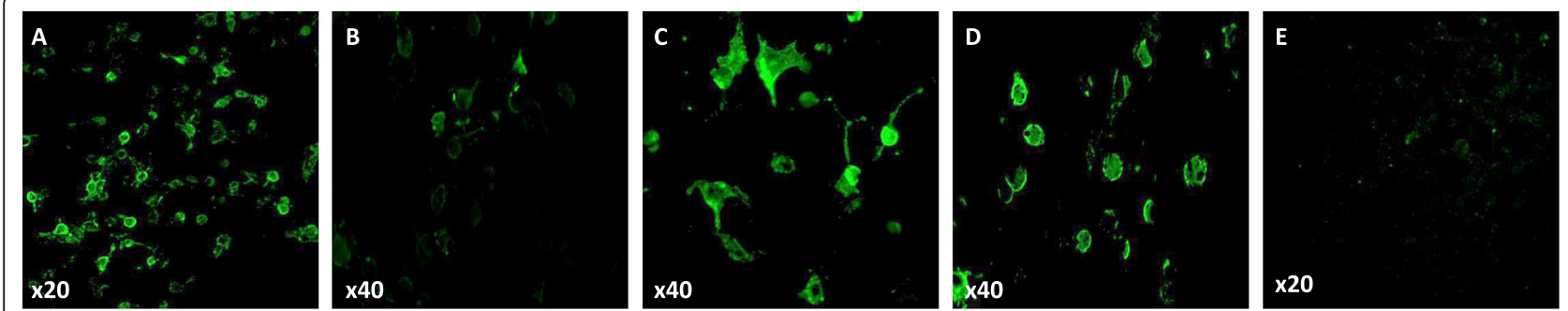

Fig. 1 Undiluted CSF antibodies binding to NMDA-NR1 subunit-transfected HEK293T cells (Autoimmune encephalitis mosaic-6, EUROIMMUN, Lübeck, Germany) detected using fluorescein isothiocyanate-conjugated human IgG. a CSF positive (scored 2) $\times 20 ; \mathbf{b}$ CSF positive (scored 1) $\times$ 40; c CSF positive (scored 2) × 40; $\mathbf{d}$ positive commercial control $\times$ 40; e CSF negative (scored 0). Immunofluorescence intensity was scored as 2 (=positive control); as 1 for low positive; and as 0 for negative. NMDAR = N-methyl-D-aspartate receptor, HEK = Human embryonic kidney

\section{Data analysis}

Statistical analysis was done using SPSS Statistics 26 software. Pearson's chi-squared test was used to determine whether there is a statistically significant difference between categories compared.

\section{Results}

A total of 142 patients from 21 of the 25 districts of Sri Lanka fulfilling criteria for 'possible' AE [10] were referred by neurologists for inclusion. Almost a fifth of the study population was from the district of Colombo. Patient ages ranged from 1 to 86 years ( mean $=27.8$; $\mathrm{SD}=20.3)$ and most were female $(61.3 \%)$.
Of the 142 patients with 'possible' AE, 71 (50\%) fulfilled diagnostic criteria of 'probable' NMDARE or LE [10] (Fig. 2). Clinical characteristics, investigation findings, treatment and outcome of antibody-positive and antibody-negative AE patients are given in Table 1.

Sixty-five patients (mean age $=25.6$ years; $S D=20.3$; $49.2 \%$ less than 18 years of age; $64.6 \%$ females) fulfilled diagnostic criteria for 'probable' NMDARE [10]. Abnormal behaviour (95.3\%), seizures (81.5\%) and movement disorders (69.2\%) were the most frequent clinical manifestations while speech dysfunction (46.1\%) and dysautonomia $(24.6 \%)$ were less common. No ovarian or other tumours were detected in imaging studies (MRI or CT,

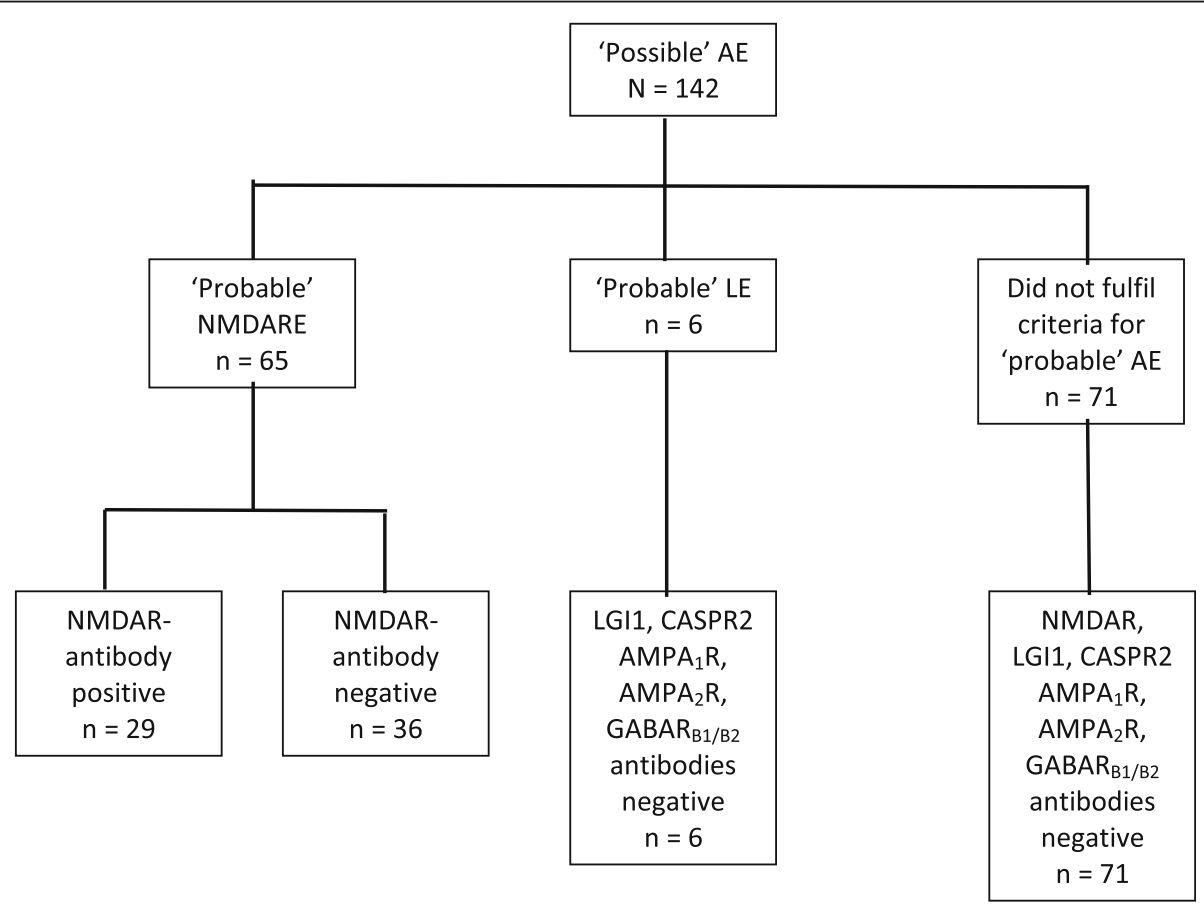

Fig. 2 Algorithm of diagnosis of autoimmune encephalitis using a clinical approach and neuroglial surface autoantibody testing. Patients presenting with encephalitis were classified as 'possible' and 'probable' AE based on Graus criteria [10]. CSF was tested first. Serum was tested only in those without detectable antibodies in CSF. None were seropositive. AE = autoimmune encephalitis; NMDARE =N-methyl-D-aspartate receptor antibody encephalitis; $L E=$ limbic encephalitis 
Table 1 Clinical characteristics, investigation findings, treatment and outcome of antibody-positive and antibody-negative AE patients

\begin{tabular}{|c|c|c|c|c|c|}
\hline \multirow[t]{2}{*}{ Characteristic } & \multicolumn{4}{|c|}{ Clinically diagnosed NMDARE } & \multirow{2}{*}{$\begin{array}{l}\text { Clinically } \\
\text { diagnosed LE } \\
\text { n (\%) }\end{array}$} \\
\hline & $\begin{array}{l}\text { Total } \\
\text { N (\%) }\end{array}$ & $\begin{array}{l}\text { NMDAR-Ab } \\
\text { positive } \\
\mathrm{n}(\%)\end{array}$ & $\begin{array}{l}\text { NMDAR-Ab } \\
\text { negative }^{a} \\
\text { n (\%) }\end{array}$ & $\begin{array}{l}\text { NMDAR-Ab positive } \\
\text { Vs negative } \\
p \text {-value }\end{array}$ & \\
\hline Patients & $65(100)$ & $29(20.4)$ & $36(25.4)$ & & $6(4.2)$ \\
\hline Mean age (SD) & $25.6(20.3)$ & $19.3(11.9)$ & $30.7(24.1)$ & 0.01 & $47.2(17.5)$ \\
\hline Females & $42(64.6)$ & $22(75.9)$ & $20(55.5)$ & 0.09 & $5(83.3)$ \\
\hline \multicolumn{6}{|l|}{ Clinical manifestations } \\
\hline Decreased level of consciousness & $58(89.2)$ & $23(79.3)$ & $35(97.2)$ & 0.01 & $4(66.6)$ \\
\hline $\begin{array}{l}\text { Abnormal (psychiatric) behaviour or } \\
\text { cognitive dysfunction }\end{array}$ & $62(95.3)$ & $27(93.1)$ & $35(97.2)$ & 0.43 & $6(100)$ \\
\hline Amnesia/working memory deficits & $28(43.0)$ & $9(31.0)$ & $19(52.8)$ & 0.08 & $3(50)$ \\
\hline $\begin{array}{l}\text { Confusion/disorientation in time, } \\
\text { place or person }\end{array}$ & $56(86.1)$ & $24(82.8)$ & $32(88.9)$ & 0.48 & $6(100)$ \\
\hline Visual hallucinations & $19(29.2)$ & $9(31.0)$ & $10(27.8)$ & 0.77 & $1(16.6)$ \\
\hline Auditory hallucinations & $15(23.1)$ & $8(27.6)$ & $7(19.4)$ & 0.44 & 0 \\
\hline Insomnia & $24(36.9)$ & $12(41.4)$ & $12(33.3)$ & 0.50 & $3(50.0)$ \\
\hline Agitation & $36(55.4)$ & $19(65.5)$ & $17(47.2)$ & 0.14 & $5(83.3)$ \\
\hline Catatonia & $23(35.4)$ & $9(31.0)$ & $14(38.9)$ & 0.51 & 0 \\
\hline Obsessive thoughts or actions & $13(20.0)$ & $6(20.7)$ & $7(19.4)$ & 0.90 & 0 \\
\hline Speech dysfunction & $30(46.1)$ & $7(24.1)$ & $23(63.9)$ & 0.001 & 0 \\
\hline Seizures & $53(81.5)$ & $25(86.2)$ & $28((77.7)$ & 0.38 & $6(100)$ \\
\hline Focal & $32(49.2)$ & $15(51.7)$ & $17(47.2)$ & 0.72 & $2(33.3)$ \\
\hline Generalised & $34(52.3)$ & $15(51.7)$ & $19(52.8)$ & 0.93 & $4(66.6)$ \\
\hline Status epilepticus & $18(27.7)$ & $9(31.0)$ & $9(25)$ & 0.59 & $1(16.6)$ \\
\hline Faciobrachial dystonic seizures & 0 & 0 & 0 & 0 & 0 \\
\hline Movement disorders & $45(69.2)$ & $17(58.6)$ & $28(77.7)$ & 0.09 & 0 \\
\hline Orofacial dyskinesia & $30(46.2)$ & $11(37.9)$ & $19(52.8)$ & 0.23 & 0 \\
\hline Limb dyskinesia & $25(38.2)$ & $10(34.5)$ & $15(41.7)$ & 0.55 & 0 \\
\hline Parkinsonism & $5(7.7)$ & $1(3.4)$ & $4(11.1)$ & 0.25 & 0 \\
\hline Dysautonomia & $16(24.6)$ & $6(20.6)$ & $10(27.7)$ & 0.51 & 0 \\
\hline Hyperhidrosis & $4(6.2)$ & $2(6.9)$ & $2(5.6)$ & 0.83 & 0 \\
\hline Hypersalivation & $9(13.8)$ & $4(13.8)$ & $5(13.9)$ & 0.99 & 0 \\
\hline Fluctuating heart rate & $6(9.2)$ & $2(6.9)$ & $2(5.6)$ & 0.56 & 0 \\
\hline Fluctuating blood pressure & $4(6.2)$ & $2(6.9)$ & $2(5.6)$ & 0.83 & 0 \\
\hline Central hypoventilation & 0 & 0 & 0 & & 0 \\
\hline Tumours & 0 & 0 & 0 & & 0 \\
\hline \multicolumn{6}{|l|}{ Investigations } \\
\hline $\begin{array}{l}\text { CSF protein elevated (number/of } \\
\text { available data) }\end{array}$ & 21/57 (36.8) & $7 / 24(29.2)$ & $14 / 33(42.2)$ & 0.31 & $3 / 5(60.0)$ \\
\hline CSF pleocytosis (number/of available data) & 22/58 (37.9) & 10/26 (38.5) & 12/32 (37.5) & 0.94 & $5 / 5(100.0)$ \\
\hline Abnormal EEG (number/of available data) & $46 / 56(82.1)$ & 14/22 (63.6) & $32 / 34(94.1)$ & 0.003 & $2 / 4(50.0)$ \\
\hline Abnormal MRI (number/of available data) & $13 / 40(32.5)$ & $4 / 16(25.0)$ & $9 / 24(37.5)$ & 0.41 & $1 / 3(33.3)$ \\
\hline \multicolumn{6}{|l|}{ Treatment } \\
\hline Intravenous methylprednisolone & $41(63.0)$ & $20(68.9)$ & $21(58.3)$ & 0.38 & $6(100)$ \\
\hline Intravenous immunoglobulins & $34(52.3)$ & $17(58.6)$ & $17(47.2)$ & 0.36 & $2(33.3)$ \\
\hline
\end{tabular}


Table 1 Clinical characteristics, investigation findings, treatment and outcome of antibody-positive and antibody-negative AE patients (Continued)

\begin{tabular}{|c|c|c|c|c|c|}
\hline \multirow[t]{2}{*}{ Characteristic } & \multicolumn{4}{|c|}{ Clinically diagnosed NMDARE } & \multirow{2}{*}{$\begin{array}{l}\text { Clinically } \\
\text { diagnosed LE } \\
\text { n (\%) }\end{array}$} \\
\hline & $\begin{array}{l}\text { Total } \\
\mathrm{N}(\%)\end{array}$ & $\begin{array}{l}\text { NMDAR-Ab } \\
\text { positive } \\
\text { n (\%) }\end{array}$ & $\begin{array}{l}\text { NMDAR-Ab } \\
\text { negative }^{a} \\
\text { n (\%) }\end{array}$ & $\begin{array}{l}\text { NMDAR-Ab positive } \\
\text { Vs negative } \\
p \text {-value }\end{array}$ & \\
\hline Plasmapheresis & $35(53.8)$ & $19(65.5)$ & $16(44.4)$ & 0.09 & 0 \\
\hline Rituximab & $6(9.2)$ & $4(13.8)$ & $2(5.5)$ & 0.25 & 0 \\
\hline Mycophenolate mofetil & $2(3.0)$ & $1(3.4)$ & $1(2.7)$ & 0.25 & 0 \\
\hline Anti-epileptic medication & $37(56.9)$ & $16(55.1)$ & $21(58.3)$ & 0.79 & $4(66.6)$ \\
\hline \multicolumn{6}{|l|}{ Outcome at one-year review } \\
\hline Recovery to $\mathrm{mRS}<3$ (number/of available data) & $41 / 60(68.3)$ & $23 / 29(79.3)$ & 18/31 (58.0) & 0.07 & $3 / 5(60.0)$ \\
\hline Deaths & $14 / 60(23.3)$ & $4(13.8)$ & $10(27.8)$ & 0.17 & $2(33.3)$ \\
\hline
\end{tabular}

${ }^{a}$ CSF was tested first. Serum was tested only in those without detectable antibodies in CSF. None were seropositive

depending on availability). EEG was the most sensitive investigation in detecting cerebral abnormality (82.1\%) while MRI and CSF analysis were abnormal only in about a third of patients with probable NMDARE. EEG abnormalities comprised epileptic and/or slow wave discharges. None of the investigation findings were specific. Most patients received either one or a combination of first line immunosuppressive/immunomodulatory therapy (intravenous methyl prednisolone $1 \mathrm{~g} / \mathrm{d}$ for 5 days; intravenous immunoglobulins $0.4 \mathrm{~g} / \mathrm{kg} / \mathrm{d}$ for 5 days; 5 cycles of plasmapheresis every other day) while $9.2 \%$ received second line immunotherapy (rituximab $375 \mathrm{mg} / \mathrm{m}^{2} \times 4$ doses at weekly intervals). More than half of the probable NMDARE patients required antiepileptic medication. At one-year review, 14 (23.3\%) had died, $41(68.3 \%)$ had a good outcome $(\mathrm{mRS}<3)$ and $8.3 \%$ had persistent disabling deficits. Five were lost to follow up. Five of the six patients (83.3\%) who received rituximab had a good outcome.

Of the 65 patients with probable NMDARE on clinical grounds, only 29 (44.6\%) had NMDAR-antibodies detectable in their CSF (Fig. 1). None of the other antibodies were detected in CSF or serum. The mean age was higher, and the female predominance less marked among the antibody-negative than the antibody-positive probable NMDARE patients. Apart for decreased level of consciousness and speech dysfunction which were more frequent among antibody-negative compared to antibody-positive probable NMDARE patients, the clinical manifestations did not significantly differ among the two groups. Of the investigations, EEG abnormalities were significantly higher $(p=0.003)$ among antibodynegative than antibody-positive probable NMDARE patients. There was no difference in the immunological interventions administered to the two groups, but a poorer response to treatment $(\mathrm{OR}=2.78 ; 95 \% \mathrm{CI}=0.88-9.09)$ and more deaths $(\mathrm{OR}=2.38 ; 95 \% \mathrm{CI}=0.67-8.33)$ were noted among the antibody-negative than antibody-positive patients although it did not reach statistical significance.
LE was diagnosed in 6 patients (mean age $=47.2$ years; range $28-71$ years; $83.3 \%$ females) based on clinical features suggestive of involvement of the limbic system as previously described [10]. Most patients had amnesia (50\%) and/or confusion (100\%) with agitation (83.3\%) and seizures (100\%), but none had faciobrachial dystonic seizures. CSF pleocytosis (5 of 5) and increased protein (3 of 5) were observed in the majority, but none had typical MRI findings of increased signal in the medial temporal lobes. All patients were treated with immunotherapy resulting in a good outcome $(\mathrm{mRS}<3)$ in $60 \%$.

Microbiological screening of the patients with 'probable' or 'definite' AE did not reveal an infectious aetiology or a concurrent CNS infection.

Of the patients remaining within the initial classification of 'possible' AE after excluding patients who fulfilled a diagnosis of 'probable' $\mathrm{AE}(n=71)$, none were positive for encephalitogenic autoantibodies. Among them, an alternative diagnosis became evident in $67.6 \%$ subsequently with evolution of the clinical syndrome and further investigations. Diagnoses included viral encephalitis (26.8\%), psychiatric illness (16.9\%), epilepsy (12.7\%), CNS demyelination (8.5\%), pyogenic meningoencephalitis, septic encephalopathy, metabolic encephalopathy, vasculitis, cerebral ischaemia and paraneoplastic encephalopathy. In the rest $(n=23)$ the diagnosis was undetermined at the time of the study.

\section{Discussion}

Among patients presenting to hospitals in Sri Lanka with a clinical syndrome of encephalitis and in whom an autoimmune aetiology was suspected as 'possible' by the attending neurologist, we found that NMDARE was the commonest form of $\mathrm{AE}$ accounting for $45.8 \%$ while $\mathrm{LE}$ accounted for only $4.2 \%$. However, NMDAR-antibodies were detected only in about half of the patients with probable NMDARE while none of the common putative antibodies were detected in LE. Although there were no 
clinical markers that could reliably differentiate between antibody-positive and antibody-negative probable NMDARE, the EEG was found to be abnormal more frequently in antibody-negative probable NMDARE while a better outcome and fewer deaths were noted among antibody-positive probable NMDARE. Among patients who did not fulfil diagnostic criteria for 'probable' AE, many subsequently were recognised to have an alternative diagnosis that initially mimicked a 'possible' AE.

Detection of antibodies against neuronal cell-surface or synaptic proteins are an essential requisite for a definite diagnosis of AE. However, since these antibody assays are not widely available, particularly in resource poor settings, and since false negative results are known to occur $[11,12]$, the syndromic approach introduced in 2016 [10] based on neurological assessment and conventional tests that are widely accessible has proven to be useful as also shown in our study. The inability to detect autoantibodies does not rule out a diagnosis of $\mathrm{AE}$, particularly if consistent with a syndromic diagnosis of $\mathrm{AE}$ and logical differential diagnosis to exclude an alternative aetiology. Antibody-negative $\mathrm{AE}$ is a recognised entity $[6,13,14]$, usually based on response to immunotherapy in clinically suggestive patients and is attributed to lack of sensitivity of the assay used, low titres, timing of the assays and the possibility of unrecognised pathogenic antibodies that are not yet tested. Indeed, more than half of the probable NMDARE patients and all the LE patients in our study were antibody negative. However, the excess antibody negativity in our study may have also been contributed by a less stringent clinical ascertainment by the on-site neurologists and a relatively lesser sensitivity of commercial, fixed cell-based assays compared to live cell-based assays [15]. It is tempting to postulate that the lower assay sensitivity may have been related to lower $\mathrm{AE}$ antibody titres among South Asians given similar results in an Indian population [14], but this has not been verified. Unlike NMDARE with a single antibody target, LE with many antibody targets and more being recognised, is more likely to be diagnosed in the absence of detectable antibodies. Immunohistochemistry on murine brain section and live cell-based assays have been shown to improve antibody detection $[15,16]$, but these methods were not available to us. Nonetheless, $67.7 \%$ of our AE patients showed a good response $(\mathrm{mRS}<3)$ to immunotherapy irrespective of their antibody status. Furthermore, most patients in our study improved with first line immunotherapy while only about one tenth required second line immunotherapy with rituximab to which the response rate was over $80 \%$ consistent with previous observations [3]. Interestingly, our data seem to suggest a better outcome among patients with detectable antibodies than those without.
Abnormal (psychiatric) behaviour or cognitive dysfunction, seizures and movement disorders were the commonest clinical manifestations of probable NMDA $\mathrm{RE}$ among the South Asian patients in our study, which was not different to the clinical manifestations of NMDARE described in Caucasian populations [2, 17]. Similar to other populations, probable NMDARE in our study was common among young patients (two thirds below the age of 18 years) with a female preponderance while LE was common among older patients albeit with a female preponderance.

Since most patients initially manifest psychiatric features while movement disorders and seizures often occur at a later stage [4] and since the detection of autoantibodies in psychiatric illness does not necessarily mean an autoimmune aetiology [17], the finding of abnormalities on EEG in the majority of probable NMDARE patients in our study provides important evidence for greater reliance on EEG to classify the aetiology of psychiatric manifestations. Moreover, a significantly higher rate of EEG abnormalities among antibody-negative than antibody-positive probable NMDARE patients in our study further enhances the diagnostic utility of the EEG in the absence of a definite disease marker.

Although around half of the patients were first classified as 'possible', this did not confer any harm to the patient, but increased the diagnostic yield of 'probable' AE. Early treatment remains the cornerstone of a good outcome of $\mathrm{AE}$ [3], and in this context, the benefit of early diagnosis outweighs the disadvantage of misclassification during the early phase of the illness. Considering the response to immunotherapy in the diagnostic criteria may reduce the initial misclassification, but this is not practical because this information is not available at the time of symptom onset or early clinical evaluation. Furthermore, the lack of response to first line immunotherapy does not necessarily rule out $\mathrm{AE}$ and conceivably we may have missed some patients with $\mathrm{AE}$ in our study.

Less than 200 cases of $\mathrm{AE}$ has been reported from South Asia from among a cumulative population of 2 billion living in eight countries. This reflects a scarcity of published data rather than the occurrence of disease among the populations of this region. Our study represents the largest series of patients in a single study from South Asia. More importantly, this study enabled the establishment of cell-based assays at the Medical Research Institute in Colombo and provided the necessary evidence to convince the Ministry of Health of Sri Lanka to provide budgetary allocation to continue provision of $\mathrm{AE}$ diagnostic assays to the National Health Service which is free of charge to all citizens in Sri Lanka.

There are limitations to our study. Patients were recruited from only government hospitals with access to a neurologist, thus underrepresenting the true $\mathrm{AE}$ population. 
All patients and their investigations could not be personally examined by the research team since they were resident in many districts in the country. One year follow up data was limited to only those diagnosed with $\mathrm{AE}$, and even among them, some were lost to follow up. Not all patients had access to MRI for brain imaging, which may have influenced the initial classification of AE. An infectious aetiology may have been more commonly identified had more specialised microbiological investigations been utilised in this study than only the routine investigations that were used. Indeed, in $16 \%$ of patients with possible $\mathrm{AE}$, the aetiology remained undetermined.

\section{Conclusions}

Our study adds to fill the hiatus of evidence of the frequency, clinical manifestations and prevalence of autoantibodies against neuronal cell-surface/synaptic proteins in $\mathrm{AE}$ among South Asians, illustrates the real world evaluation of the syndromic approach in establishing a diagnosis when antibodies are unavailable and suggests a greater reliance on EEG as a marker to evaluate for an autoimmune basis for psychiatric symptoms.

\section{Abbreviations}

Ab: Antibody; AE: Autoimmune encephalitis; AMPAR: a-amino-3-hydroxy-5methyl-4-isoxazolepropionic acid receptor; CASPR2: Contactin-associated protein-like 2; CBA: Cell-based assay; CSF: Cerebrospinal fluid;

$\mathrm{CT}$ : Computerised tomography; EEG: Electroencephalogram; GABAB: - $^{-}$ aminobutyric acid B; HEK: Human embryonic kidney; LE: Limbic encephalitis; LGI1: Leucine-rich glioma-inactivated protein 1; MRI: Magnetic resonance imaging; NMDAR: N-methyl D-aspartate receptor; NMDARE: NMDAR-antibody encephalitis

\section{Acknowledgements}

We are grateful to all the neurologists who referred patients and specimens for this study, Mr. Wasantha Pushpakumara, senior medical laboratory technologist at the Department of Immunology, Medical Research Institute, Colombo who assisted in performing the antibody assays and Prof Angela Vincent, Emeritus Professor of Neuroimmunology, University of Oxford, United Kingdom for her constructive comments on this manuscript.

\section{Authors' contributions}

All authors were involved in the conceptualisation and design of the study. NW acquired, clarified and analysed the data. TC wrote the first draft of the paper. NW, DD, NM and RDS critically appraised the paper for its intellectual content. The authors read and approved the final manuscript.

\section{Funding}

This work was supported by research grants from the Medical Research Institute, Colombo, Sri Lanka (research grant number - 2017/7) and the Association of Sri Lankan Neurologists (2018). The funding bodies did not have any influence on the study design or on collection, analysis, and interpretation of data or on writing the manuscript.

\section{Availability of data and materials}

All relevant data generated or analysed during this study are included in this published article.

\section{Declarations}

\section{Ethics approval and consent to participate}

The study was approved by the Ethics Review Committee of the Medical Research Institute, Colombo, Sri Lanka (Project No. 07/2017). Written informed consent was obtained from either the patient or guardian.
Consent for publication

Not applicable.

\section{Competing interests}

The authors declare that they have no relevant competing interests.

\section{Author details}

${ }^{1}$ Department of Physiology, University of Colombo, Colombo, Sri Lanka. ${ }^{2}$ Department of Immunology, Medical Research Institute, Colombo, Sri Lanka. ${ }^{3}$ Department of Immunology and Molecular Medicine, University of Sri Jayawardenapura, Nugegoda, Sri Lanka. ${ }^{4}$ Department of Clinical Medicine, Faculty of Medicine, University of Colombo, 25, Kynsey Road, Colombo 00800, Sri Lanka.

Received: 15 January 2021 Accepted: 10 May 2021

Published online: 19 May 2021

\section{References}

1. Granerod J, Ambrose HE, Davies NW, Clewley JP, Walsh AL, Morgan D, et al. Causes of encephalitis and differences in their clinical presentations in England: a multicentre, population-based prospective study. Lancet Infect Dis. 2010;10(12):835-44. https://doi.org/10.1016/S1473-3099(10)70222-X.

2. Dalmau J, Graus F. Antibody-mediated encephalitis. N Engl J Med. 2018; 378(9):840-51. https://doi.org/10.1056/NEJMra1708712 PMID: 29490181.

3. Titulaer MJ, McCracken L, Gabilondo I, Armangue T, Glaser C, lizuka T, et al. Treatment and prognostic factors for long-term outcome in patients with anti-NMDA receptor encephalitis: an observational cohort study. Lancet Neurol. 2013;12(2):157-65. https://doi.org/10.1016/S1474-4422(12)70310-1.

4. Irani SR, Bera K, Waters P, Zuliani L, Maxwell S, Zandi MS, et al. N-methyl-Daspartate antibody encephalitis: temporal progression of clinical and paraclinical observations in a predominantly non-paraneoplastic disorder of both sexes. Brain. 2010;133(Pt 6):1655-67. https://doi.org/10.1093/brain/a Wq113 PMID: 20511282; PMCID: PMC2877907.

5. Irani SR, Michell AW, Lang B, Pettingill P, Waters $P$, Johnson MR, et al. Faciobrachial dystonic seizures precede Lgi1 antibody limbic encephalitis. Ann Neurol. 2011;69(5):892-900. https://doi.org/10.1002/ana.22307 Epub 2011 Mar 17. PMID: 21416487.

6. Cyril AC, Nair SS, Mathai A, Kannoth S, Thomas SV. Autoimmune encephalitis: clinical diagnosis versus antibody confirmation. Ann Indian Acad Neurol. 2015;18(4):408-11. https://doi.org/10.4103/0972-2327.165454.

7. Dash D, Ihtisham K, Tripathi M, Tripathi M. Proportion and spectrum of movement disorders in adolescent and adult patients of autoimmune encephalitis of non-neoplastic aetiology. J Clin Neurosci. 2019;59:185-9. https://doi.org/10.1016/j.jocn.2018.10.076 Epub 2018 Nov 16. PMID: 30455136.

8. Sheikh S, Ahmad A, Ahmed TA. Anti NMDA receptor antibody encephalitis in Pakistan: Clinicopathological features and treatment outcomes. J Pak Med Assoc. 2019;69(12):1910-4. https://doi.org/10.5455/JPMA.300185 PMID: 31853128.

9. Wanigasinghe J, Chang T, Vincent A. Treatment-responsive, reversible, autoimmune encephalitis in a child. Ceylon Med J. 2012;57(2):90-1. https:// doi.org/10.4038/cmj.v57i2.4466

10. Graus F, Titulaer MJ, Balu R, Benseler S, Bien CG, Cellucci T, et al. A clinical approach to diagnosis of autoimmune encephalitis. Lancet Neurol. 2016; 15(4):391-404. https://doi.org/10.1016/S1474-4422(15)00401-9 Epub 2016 Feb 20. PMID: 26906964; PMCID: PMC5066574.

11. Gresa-Arribas N, Titulaer MJ, Torrents A, Aguilar E, McCracken L, Leypoldt F, et al. Antibody titres at diagnosis and during follow-up of anti-NMDA receptor encephalitis: a retrospective study. Lancet Neurol. 2014;13(2):16777. https://doi.org/10.1016/S1474-4422(13)70282-5 Epub 2013 Dec 18. Erratum in: Lancet Neurol. 2014 Feb;13(2):135. PMID: 24360484; PMCID: PMC4006368.

12. Binks SNM, Klein CJ, Waters P, Pittock SJ, Irani SR. LGI1, CASPR2 and related antibodies: a molecular evolution of the phenotypes. J Neurol Neurosurg Psychiatry. 2018;89(5):526-34. https://doi.org/10.1136/jnnp-2017-315720 Epub 2017 Oct 21. PMID: 29055902; PMCID: PMC5909759.

13. Hacohen Y, Wright S, Waters P, Agrawal S, Carr L, Cross H, et al. Paediatric autoimmune encephalopathies: clinical features, laboratory investigations and outcomes in patients with or without antibodies to known central nervous system autoantigens. J Neurol Neurosurg Psychiatry. 2013;84(7): 
748-55. https://doi.org/10.1136/jnnp-2012-303807 Epub 2012 Nov 22. PMID: 23175854; PMCID: PMC3686256.

14. Pradhan S, Das A, Das A, Mulmuley M. Antibody negative autoimmune encephalitis- does it differ from definite one? Ann Indian Acad Neurol. 2019; 22(4):401-8. https://doi.org/10.4103/aian.AIAN_206_19 Epub 2019 Oct 25. PMID: 31736559; PMCID: PMC6839299.

15. McCracken L, Zhang J, Greene M, Crivaro A, Gonzalez J, Kamoun M, et al. Improving the antibody-based evaluation of autoimmune encephalitis. Neurol Neuroimmunol Neuroinflamm. 2017;4(6):e404. https://doi.org/1 0.1212/NXI.0000000000000404 PMID: 29075658; PMCID: PMC5639462.

16. Bien CG. Diagnosing autoimmune encephalitis based on clinical features and autoantibody findings. Expert Rev Clin Immunol. 2019;15(5):511-27. https://doi.org/10.1080/1744666X.2019.1573676 Epub 2019 Mar 5. PMID: 30676128.

17. Dalmau J, Armangué T, Planagumà J, Radosevic M, Mannara F, Leypoldt $F$, et al. An update on anti-NMDA receptor encephalitis for neurologists and psychiatrists: mechanisms and models. Lancet Neurol. 2019;18(11):1045-57. https://doi.org/10.1016/S1474-4422(19)30244-3 Epub 2019 Jul 17. PMID: 31326280 .

\section{Publisher's Note}

Springer Nature remains neutral with regard to jurisdictional claims in published maps and institutional affiliations.

Ready to submit your research? Choose BMC and benefit from:

- fast, convenient online submission

- thorough peer review by experienced researchers in your field

- rapid publication on acceptance

- support for research data, including large and complex data types

- gold Open Access which fosters wider collaboration and increased citations

- maximum visibility for your research: over $100 \mathrm{M}$ website views per year

At BMC, research is always in progress.

Learn more biomedcentral.com/submissions 